\title{
Pengaruh Dana Pihak Ketiga (DPK) Mudharabah Anggota dan Liability Lembaga Lain Terhadap Return On Equity (Study Pada Lembaga Keuangan Syariah Non Bank di Tulungagung dan Blitar)
}

Submission date: 07-Oct-2021 09:44AM (UTC+0700)

Submission ID: 1667396479

File name: Pengaruh_DPK_Mudharabah_Anggota_dan_Liability.pdf (718.84K)

Word count: 11304

Character count: 68987 


\title{
lqtishadia
}

JURNAL EKONOMI DAN PERBANKAN SYARIAH

P-ISSN: 2354-7057; E-ISSN: 2442-3076

Vol. 5 No. 1 Juni 2018

\section{Pengaruh Dana Pihak Ketiga (DPK) Mudharabah Anggota dan Liability Lembaga Lain Terhadap Return On Equity (Study Pada Lembaga Keuangan Syariah Non Bank di Tulungagung dan Blitar)}

\author{
Binti Nur Asiyah \\ Lantip Susilowati \\ Nur Aziz Muslim \\ Institut Agama Islam Negeri Tulungagung \\ lantip_susilowati@yahoo.co.id
}

\begin{abstract}
Abstrak: Penelitian ini didasarkan oleh keterbatasan Lembaga keuangan syariah non bank (Baitul Maal wat Tamwil) dalam mengakses dana dari anggota. Undang-undang Perkoperasian tahun 2012 memberikan peluang bagi Koperasi untuk mengakses dana dari lembaga lain. Kondisi ini berdampak pada capaian keuntungan bagi pemilik ekuitas. Jika keuntungan rendah maka keberlangsungan lembaga terancam. Pemegang ekuitas memind 8 dananya ke dalam bisnis yang lebih menguntungkan. Penelitian ini bertujuan untuk; 1) Menganalis kondisi Dana Pihak Ketiga (DPK) mudharabah pada BMT Tulungagung dan Blitar. 2) Menganalis kondisi liability lembaga lain pada BMT di Tulungagung dan Blitar. 3). Menganalis kondisi return on equity pada BMT di Tulungagung dan Blitar. 4) Menguji pengaruh signifikan Dana Pihak Ketiga (DPK) mudharabah terhadap return on equity pada BMT di Tulungagung dan Blitar. 5) Menguji adanya pengaruh signifikan liability lembaga lain terhadap return on equity BMT di Tulungagung dan Blitar. 6) Menguji adanya pengaruh signifikan Dana Pihak Ketiga (DPK) mudharabah dan liability lembaga lain terhadap return on equity BMT di Tulungagung dan Blitar. Penelitian ini dilakukan dengan dengan pendekatan kuantitatif dengan jenis penelitian assosiatif. Analisis data dilakukan dengan uji normalitas data, uji asumsi klasik (Multikolineritas, heterokedastisitas, autokorelasi), uji regresi berganda, uji hipotesa, uji koefisien determinasi. Hasil dari penelitian ini adalah 1). Kondisi Dana Pihak Ketiga (DPK) mudharabah anggota mengalami fluktuasi baik di Tulungagung maupun, di Blitar cenderung mengalami penurunan. 2)Kondisi liability lembaga lain lebih banyak dibutuhkan di Blitar, dibandingkan di Tulungagung. 3). Kondisi return on equity lebih besar di dapat d Blitar daripada di Tulungagung. 4) DPK mudharabah
\end{abstract}


Pengaruh Dana Pihak Ketiga (DPK) Mudharabah Anggota

dan Liability Lembaga Lain Terhadap Return On Equity

(Study Pada Lembaga Keuangan Syariah Non Bank di Tulungagung dan Blitar)

berpengaruh positif namun tidak signifikan secara statistik terhadap return on equity BMT di Tulungagung dan Blitar. 5)Liability pada lembaga lain memberikan pengaruh negatif dan tidak signifikan secara statistik terhadap return on equity BMT di Tulungagung dan Blitar. 6) Secara simultan variabel DPK mudharabah dan liability pada lembaga lain memberikan pengaruh dan tidak signifikan secara statistik terhadap return on equity BMT di Tulungagung dan Blitar.

Kata Kunci: dana pihak ketiga (DPK); liability lembaga lain; return on equity.

Abstract: This study is based on the limitations of non-bank syariah financial institutions (Baitul Maal wat Tamwil) in accessing funds from members. The Cooperative Act of 2012 provides an opportunity for Cooperatives to access funds from other institutions. This condition has an impact on profit performance for equity owners. If the profit is low then the institution's sustainability is threatened. The equity holder moves his funds into a more profitable business. This research aims to; 1) Analyzing the condition of Third Party Funds (DPK) mudharabah at BMT in Tulungagung and Blitar. 2) Analyzing other institutions' liability conditions in BMT Tulungagung and Blitar. 3). Analyzing the condition of return on equity at BMT in Tulungagung and Blitar. 4) Test the significant influence of Third Party Funds (DPK) mudharabah on return on equity at BMT in Tulungagung and Blitar. 5) Examining the significant influence of other institutions' liability on return on equity in BMT Tulungagung and Blitar. 6) Examine the significant influence of Third Party Funds (DPK) mudharabah and other institutional liability to return on equity in BMT Tulungagung and Blitar. This research was conducted with a quantitative approach and type of associative research. Data analysis was done by data normality test, classical assumption test (Multikolineritas, heterokedastisitas, autokorelasi), multiple regression test, hypothesis test, coefficient of determination test. The results of this study are 1). The condition of Third Party Funds (DPK) mudharabah members experience fluctuations in both BMT in Tulungagung, while in Blitar tend to decrease. 2) Liability of other institutions is more needed in BMT Blitar, than in Tulungagung. 3). Return on equity is greater on BMT in Blitar than in Tulungagung. 4) Mudharabah DPK has a positive but not statistically significant effect on the return on equity of non-bank Islamic financial institutions in Tulungagung

lqtishadia Vol.5 No.1 Juni 2018 
and Blitar. 5) Liability to other institutions gives a negative and not statistically significant effect on the return on equity of nonbank Islamic financial institutions in Tulungagung and Blitar. 6) Simultaneously mudharabah DPK variable and liability at other institution give influence and not statistically significant to return on equity BMT in Tulungagung and Blitar

Key Word: third party fund (DPK); liability of other institutions; return on equit

\section{PENDAHULUAN}

Lembaga Keuangan Syariah non Bank merupakan salah satu lembaga keuangan syariah selain bank yang menerapkan prinsip-prinsip syariah dalam pengelolaan dananya. Fungsi lembaga keuangan ini mirip dengan keberadaan Bank Umum Syariah ${ }^{1}$. Pembedanya adalah jika bank umum syariah memiliki produk jasa kliring, transfer, namun pada lembaga keuangan mikro syariah, hal tersebut tidak ada. Namun demikian terkait peran fungsi intermediasi antara yang membutuhkan dana dengan yang surplus dana menjadi produk unggulan dalam lembaga keuangan mikro syariah tersebut. Kepemilikan anggota menjadi prioritas untuk menawarkan produk funding dan Financing lebih mudah. Anggota dengan mudah mengakses produk yang ditawarkan mengingat lembaga memiliki pengetahuan cukup tentang karakter anggota.

Implementasi fungsi intermediasi funding yang diterapkan Lembaga Keuangan Mikro Syariah terdiri dari simpanan pokok, simpanan wajib dan simpanan sukarela. Simpanan pokok dibayar anggota sekali selama menjadi anggota, sedangkan simpanan wajib merupakan simpanan rutin anggota yang dibayar kepada lembaga sesuai kemampuan dan kesepakatan antara anggota dengan lembaga. Selain itu simpanan sukarela dibayar anggota kepada lembaga pada saat anggota memiliki surplus dana. Dari sumber dana tersebut lembaga mengelola dana funding ke dalam asset produktif dalam bentuk surat berharga, piutang, pembiayaan maupun jasa.

Perkembangan Lembaga Keuangan Mikro Syariah sejalan dengan perkembangan Bank Umum Syariah. Pada Bank Umum Syariah, Dana Pihak Ketiga yang berhasil dikumpulkan terus meningkat. ${ }^{2}$ Namun

${ }^{1}$ Fungsi Dasar bank menurut Zaenul Arifin (2009). hlm2 adalah menyediakan tempat untuk menitipkan uang dengan aman (safe keeping funtion)dan menyediakan alat pembayaran untuk membeli barang dan jasa (transaction funtion)

${ }^{2}$ Dana pihak ketiga yang berhasil dikumpulkan oleh Bank umum Syariah secara umum terus mengalami kenaikan. Namun jika dilihat dari pertumbuhannya mengalami 


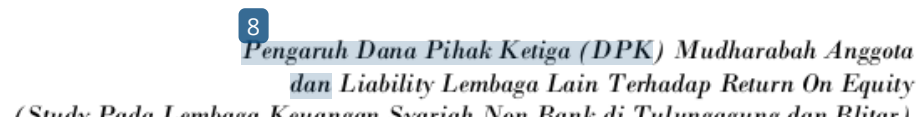

(Study Pada Lembaga Keuangan Syariah Non Bank di Tulungagung dan Blitar)

pertumbuhannya mengalami perlambatan. Perlambatan tersebut tentu berdampak pada semua upaya untuk mencapai produktifitas di Bank Syariah dan Lembaga keuangan syariah lainnya.

Sumber Dana Pihak Ketiga merupakan sumber dana yang relatif murah, mengingat keuntungan yang harus dibayarkan hanya khusus kepada para anggota yang memiliki simpanan baik berupa tabungan maupun deposito. Namun demikian, banyak sedikitnya dana murah akan sangat tergantung oleh kondisi perekonomian dan kondisi masyarakat yang siap untuk menyimpan dananya di Lembaga Keuangan Syariah. Masyarakat tertarik untuk menjadi anggota Lembaga Keuangan Syariah memerlukan strategi khusus.

Dampak dari minimalnya anggota yang menyimpan dana di Lembaga Keuangan syariah, menyebabkan lembaga keuangan syariah mencari sumber dana alternatif yang diperoleh dari lembaga lain baik dalam bentuk pinjaman, pembiayaan. Dana tersebut merupakan dana yang relatif mahal mengingat lembaga keuangan harus memikirkan keuntungan yang harus dibayar kepada nasabah lembaga keuangan syariah. Lembaga Keuangan Syariah seperti halnya Bank Umum Syariah menunjukkan bahwa sumber dana mahal yang terdapat dalam Bank Umum syariah mengalami kenaikan, dan pada akhirnya mengalami penurunan. ${ }^{3}$

Liability pada lembaga lain sebagaimana data Bank Umum Syariah terdiri dari Kewajiban pada Bank Indonesia, Kewajiban pada Bank Lain, Surat berharga yang diterbitkan, pinjaman diterima, dan kewajiban lainnya. Hal tersebut masih menjadi pilihan bagi Bank Umum Syariah.

Peningkatan hutang memper 3 aruhi besar kecilnya laba bagi Lembaga Keuangan Mikro Syariah, yang mencerminkan kemampuan perusahaan dalam memenuhi semua kewajibannya, yang ditunjukkan oleh beberapa bagian modal sendiri yang digunakan untuk membayar seluruh kewajibannya. Semakin besar hutang maka akan semakin besar kewajiban Lembaga. artinya pembayaran kewajiban/hutang tersebut lebih diprioritaskan dari pada mengejar keuntungan untuk pemegang

perlambatan. Data menunjukkan bahwa pada tahun 2010 Dana Pihak ketiga tumbuh sebesar 45\% dibanding tahun 2009 dan pada tahun 2011 tumbuh sebesar 51\% dibanding tahun 2010. Namun demikian pada tahun berikutnya, tahun 2012, 2013 dan 2014 tumbuh sebesar 27\%, 24\% dan 18\% (Statistik Perbankan Syariah Juni 2015)

${ }^{3}$ Liability pada lembaga lain pa tahun 2014 menunjukkan penurunan 36 persen, namun pada pertengahan tahun 2015 liability pada bank lain mulai merangkak naik mencapai 11 persen.

lqtishadia Vol.5 No.1 Juni 2018 
saham. Pemegang saham menjadi prioritas setelah sustainability bisinis di pasa aman. Hal ini akan menjadi bom waktu 3 ada saat lembaga dalam jangka panjang tidak menjadi pertimbangan. Jika DER semakin tinggi, maka kemampuan perusahaan untuk mendapatkan profitabilitas akan semakin rendah sehingga DER mempunyai hubungan negatif dengan profitabilitas. Hal tersebut dimotivasi oleh hasil penelitian, Myers (1984), Gordon Donaldson (1961) dan Breadly (1984), Titman dan Wessels (1988), dalam penelitian Sofiati (2001). Realita penelitian diatas menunjukkan bahwa adanya perbedaan hasil penelitian tentang hubungan hutang dengan profitabilitas.

Sumber dana mahal menjadi pilihan lembaga keuangan syariah non bank disebabkan keterbatasan sumber dana yang berasal dari anggota serta larangan Lembaga keuangan syariah menghimpun dana dari masyarakat langsung. Solusi atas keterbatasan sumber dana memberikan pilihan kepada lembaga keuangan mikro untuk bersinergi dengan lembaga keuangan syariah lainnya yang pada umumnya berjejaring dengan Bank Umum syariah atau Unit Usaha Syariah.

Asset BMT di Tulungagung pada tahun 2014 cukup beragam. Asset tersebut antara lain; di BMT Harum Rp. 7.131.135.440,-, BMT Istiqomah sebesar Rp. 17.658.061.391,-, Kopsyah Mu'amalah sebesar Rp. 2.721.941.098,-, BMT Sinar Amanah sebesar 562.477.836,- di BMT Sahara sebesar Rp. 11.574.315.532,- di BMT Dinar Amanu Rp. 2.590.019.500,- dan di BMT Pahlawan sebesar Rp. 31.674.381.467,-.4 Data tersebut menunjukkan keberagaman perkembangan asset di Tulungagung. Dari data asset BMT tersebut, salah satu yang memanfaatkan sumber dana dari lembaga lain adalah Kopsyah Mu'amalah Tulungagung. Oleh karenanya keadaan demikian menjadi satu ketertarikan bagi penulis untuk meneliti lebih jauh terkait dengan sumber dana yang dimiliki dikaitkan dengan keuntungan yang diharapkan oleh pemilik modal.

Permasalahan keuntungan para pendiri lembaga keuangan syariah menjadi tanda tanya besar sumber dana yang dikelola berasal dari liability lembaga lain yang merupakan sumber dana yang relatif mahal. Hal tersebut muncul dalam rasio keuangan return on equaty, dimana keuntungan yang didapat dibagi atas ekuitas yang dimiliki. Dengan demikian, penting kiranya untuk dilakukan penelitian "Pengaruh dana pihak ketiga mudharabah anggota dan liability pada bank lain

${ }^{4}$ Diolah dari RAT masing-masing BMT di bawah Naungan PINBUK Tulungagung. 
terhadap return on equity" (study pada Lembaga Keuangan Syariah non Bank di Tulungagung dan Blitar).

\section{METODE PENELITIAN}

Pendekatan penelitian yang digunakan penelitian ini adalah pendekatan penelitian kuantitatif. Penelitian kuantitatif merupakan "penelitian dengan meneliti seberapa besar pengaruh variabel bebas (independent) terhadap variabel terikat (dependent)"..$^{5}$ Sedangkan jenis penelitian yang digunakan adalah jenis asosatif dimana bertujuan untuk mengetahui hubungan antara dua variabel atau lebih. Dengan penelitian ini maka akan dapat dibangun suatu teori yang dapat berfungsi untuk menjelaskan, meramalkan, dan mengontrol suatu gejala". ${ }^{6}$

Populasi adalah wilayah generalisasi yang terdiri atas obyek/subyek yang mempunyai kualitas dan karakteristik tertentu yang ditetapkan oleh peneliti untuk dipelajari dan kemudian ditarik kesimpulannya. ${ }^{7}$ Populasi yang hendak dijadikan obyek penelitian dalam proposal ini yaitu laporan keuangan Kopsyah Mu'amalah Tulungagung dan BMT Podojoyo Blitar. Sedangkan sampling dalam penelitian ini dengan 8 enggunakan purposive sampling (sampel bertujuan). Sehingga sampel dalam penelitian ini adalah sebagian dari laporan keuangan Kopsyah Mu'amalah Tulungagung dan BMT Podojoyo Blitar.

Analisis data dalam penelitian dengan menggunakan uji normalitas, uji asumsi klasik, uji regressi linier berganda, uji hipotesis, dan uji koefisien determinasi.

Regresi berganda bertujuan untuk mempelajari hubungan antara dua variabel. Model regresi berganda adalah $" \hat{y}=a+b_{1} x_{1}+b_{2} x_{2}+e$, dimana, $\hat{y}$ adalah variabel terikat dan $\mathrm{X}$ adalah variabel bebas, a adalah penduga bagi intersep $(\alpha)$, b adalah penduga bagi koefisien regresi $(\beta)$, dan $\alpha, \beta$ adalah parameter yang nilainya tidak diketahui sehingga diduga menggunakan statistik sampel" .

Keterangan:

$$
\begin{array}{ll}
\mathrm{Y} & =\text { Return on Equety } \\
\mathrm{X}_{1} & =\text { Liability pada lembaga lain } \\
\mathrm{X}_{2} & =\text { DPK Mudharabah }
\end{array}
$$

5Sugiono, "Statistik Untuk Penelitian", Alfabeta, Bandung, 2006. hlm 11

${ }^{6}$ Ahmad Tanzeh dan Suyitno, "Dasar-Dasar Penelitian", Lembaga Kajian Agama dan Filsafat (eLKAF), Surabaya, 2006, hlm 45.

${ }^{7}$ Sugiyono, "Metode Penelitian Kuantitatif, Kualitatif dan R\&D", Alfabeta, Bandung, 2011. Hlm. 80 


\section{HASIL DAN PEMBAHASAN}

Kondisi Dana Pihak Ketiga (DPK) Anggota Mudharabah

Implementasi pengelolaan dana pada Lembaga Keuangan Syariah non Bank mengalami berbagai dinamika dan konteks yang memaksa untuk adaptasi terhadap lingkungan persaingan baik syariah maupun konvensional.

Nilai simpanan anggota dari akad mudharabah mengalami kenaikan 3,99\% pada awal tahun 2017 (Rp. 573.399.235,-) , dan pada bulan April 2017 mengalami penurunan sebesar 62,71\% (Rp. 226.229.575,-) dibanding bulan Maret pada tahun yang sama. Pada bulan-bulan berikutnya juga terus mengalami penurunan. Perlu dilihat bagaimana kondisi dana pihak ketiga (DPK) mudharabah pada lembaga keuangan Syariah non Bank di Blitar. (Laporan Keuangan BMT). Jumlah Dana pihak ketiga mudharabah pada Lembaga keuangan syarian non Bank di Blitar cukup stabil jika dibandingkan dengan dengan dana pihak ketiga mudharabah di Tulungagung. Januari 2017 meningkat sebesar 873.576.215,- atau meningkat sebesar 5,98\% dibandingkan bulan sebelumnya. Bulan-bulan berikutnya bersifat fluktuatif, namun penurunan terbesar pada bulan juni sebesar 9,46\%. (Laporan Keuangan BMT).

Kondisi dana pihak ketiga mudharabah pengelolaannya, lembaga keuangan syariah non bank betul-betul dihadapkan pada tingkat persaingan yang luar biasa. Baik persaingan sesama Lembaga Keuangan Syariah maupun konvensional. fluktuasi yang terjadi pada pengelolaan dana simpanan anggota dari akad mudharabah di Tulungagung mengalami kenaikan pada awal tahun, menurun pada bulan April 2017 mengalami penurunan, berikut juga pada tahun berikutnya juga terus mengalami penurunan. Penurunan tajam terjadi pada bulan April, dimana penurunan sebesar $62,71 \%$ dibanding bulan Maret pada tahun yang sama. Pada kondisi ekternal inflasi menyumbang sebesar 0,09 persen. ${ }^{8}$

Kondisi dana pihak ketiga (DPK) mudharabah pada lembaga keuangan Syariah non Bank di Blitar memberikan titik kejelasan bahwa adanya penurunan dana pihak ketiga mudharabah. Namun jika dibandingkan dengan dana pihak ketiga mudharabah di Tulungagung, Blitar termasuk masih stabil. Tidak terlalu tajam penurunannya. Menurut penelitian Faizi $^{9}$ yang meneliti tentang faktor yang

${ }^{8}$ BPS; Inflasi April 2017, diakses melalui http://m.liputan6.com

${ }^{9}$ Faizi, Faktor-Faktor Yang Mempengaruhi Simpanan Mudharabah Pada Bank Umum Syariah (Periode 2005-2007). Skripsi thesis, UIN Sunan Kalijaga Yogyakarta, 2010 


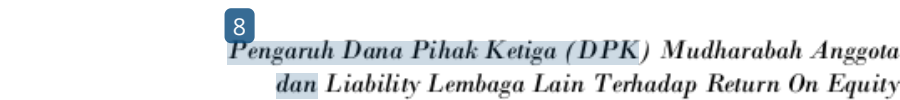

dan Liability Lembaga Lain Terhadap Return On Equity

(Study Pada Lembaga Keuangan Syariah Non Bank di Tulungagung dan Blitar)

mempengaruhi simpanan mudharabah pada Bank Umum Syariah tahun (4007 dengan analisis regresi linier berganda menghasilkan bahwa pendapatan berpengaruh signifikan terhadap simpanan mudharabah (deposito). Sedangkan untuk variabel suku bunga, dan inflasi tidak berpengaruh signifikan terhadap simpanan mudharabah (baik tabungan dan deposito). Pada uji f menunjukkan bahwa variabel independen (tingkat bagi hasil (tabungan maupun deposito), suku bunga, pendapatan dan inflasi) secara bersama-sama berpengaruh secara signifikan terhadap simpanan mudharabah pada Bank Umum Syariah. Adapun koefisien determinasi (adjusted r square R2 ) pada simpanan mudharabah (tabungan) sebesar 0,422, artinya bahwa 42,2 \% simpanan mudharabah dapat dijelaskan oleh keempat variabel bebas yang terdiri dari tingkat bagi hasil tabungan, suku bunga, pendapatan dan inflasi. Sedangkan sisanya sebesar $57,8 \%$ dipengaruhi oleh variabel lain yang tidak dimasukkan dalam model penelitian. Sedangkan koefisien determinasi (adjusted $\mathrm{r}$ square R2 ) pada simpanan mudharabah (deposito) adalah sebesar 0,219 , artinya $21,9 \%$ simpanan mudharabah (deposito) dapat dijelaskan oleh keempat variabel bebas yang terdiri dari tingkat bagi hasil deposito, suku bunga, pendapatan, dan inflasi.

Penelitian Yulianti $\mathrm{dkk}^{10}$ yang meneliti tentang faktor yang mempengaruhi simpanan mudharabah bahwa nasabah memilih simpanan dan deposito mudharabah di Bank syariah karena alasan bagi hasil ya 11 tinggi. Sebesar 22,68 \% yang mempunyai alasan bagi hasil tinggi. Dana pihak ketiga biasanya lebih dikenal dengan dana masyarakat, merupakan dana yang dihimpun oleh bank yang berasal dari masyarakat. Pertumbuhan setiap bank sangat dipengaruhi oleh perkembangan kemampuannya menghimpun dana masyarakat, baik berskala kecil maupun besar dengan masa pengendapan yang memadai. ${ }^{11}$ Sedangkan Sumber dana yang dikelola Lembaga keuangan Syariah terdiri dari dari Sumber dana Pihak Pertama (Ekuitas), Sumber dana Pihak kedua (Hutang), sumber Dana Pihak Ketiga (DPK) dari masyarakat/anggota.

Sumber dana merupakan hal terpenting bagi kegiatan operasi Lembaga Keuangan syariah dan merupakan ukuran keberhasilan. Jika Lembaga Keuangan Syariah mampu membiayai operasinya dari sumber dana Anggota, maka akan memberikan kelancaran dalam setiap

${ }^{10}$ Devi Yulianti, Anthony Mayes, Syafril Basri, Analisis faktor -faktor yang mempengaruhi simpanan mudharabah pada Bank Mandiri Syariah cabang kota Pekanbaru, JOM FEKON Vd1 1 No. 2 Oktober 2014

${ }^{11}$ Muhammad "Manajemen Bank Syariah", UPP AMP YKPN, Yogyakarta 2002, hlm. 48.

lqtishadia Vol.5 No.1 Juni 2018 
transaksi yang terjadi. Pencarian dana ini relatif paling mudah jika dibandingkan dengan sumber lainnya. Peningkatan dana pihak ketiga Lembaga keuangan syariah disebabkan karena kepercayaan masyarakat terhadap Lembaga keuangan Syariah semakin baik dari tahun ke tahun. Ini merupakan indikasi yang cukup baik bagi pengembangan ekonomi Syariah untuk terus melakukan sosialisasi dan pendekatan kepada masyarakat agar mau menjadi anggota Lembaga Keuangan syariah.

Fungsi intermediasi BMT diantaranya adalah menerima simpanan dari masyarakat yang surplus dana. Kegiatan tersebut merupakan bagian dari sumber dana perbankan yang berasal dari sumber dana pihak ketiga. Sumber Dana Pihak Ketiga (DPK) terdiri dari Giro (nasabah), Tabungan, Deposito berjangka, sertifikat deposito berjangka serta kewajiban segera lainnya.12 Dalam Pasal 1 Nomor 20 Undang-undang No.21 Tahun 2008 disebutkan bahwa simpanan adalah dana yang dipercayakan oleh nasabah kepada Bank Syariah dan/atau unit usaha syariah berdasarkan akad wadiah atau akad lain yang tidak bertentangan dengan prinsip syariah dalam bentuk giro, tabungan, dan bentuk lain yang dipersamakan dengan itu ${ }^{13}$

Fungsi intermediasi pada Baitul Maal Wat Tamwil (BMT) diantaranya pengel laan simpanan dari anggota dalam bentuk wadi'ah dan mudharabah. ${ }^{14}$ Sumber dana ini merupakan sumber dana terpenting bagi kegiatan lembaga keuangan mikro syariah yang dikumpulkan dari para anggota. Simpanan tersebut juga merupakan kategori simpanan pihak ketiga. Sumber dana pihak ketiga di Baitul Maal Wat Tamwil (BMT) terdiri dari simpanan lancar (Tabungan) dan simpanan tidak lancar (deposito). ${ }^{15}$ Tabungan tersebut diperoleh dari anggota yang dititipkan kepada BMT dan dapat diambil sewaktu-waktu. Artinya Baitul Maal Wat Tamwil (BMT) juga menerapkan prinsip likuiditas dimana Baitul Maal Wat Tamwil (BMT) harus menyiapkan kas yang cukup untuk bisa menyediakan apabila anggota mengambil simpanan sewaktu-waktu. Berbeda dengan Deposito, deposito merupakan simpanan anggota yang dipercayakan kepada Baitul Maal Wat Tamwil (BMT) yang pengambilannya hanya dapat dilakukan pada saat jatuh tempo. Jangka waktu deposito adalah mulai dari 1, 3, 6 dan 12 bulan. Keistimewaan

\footnotetext{
12 Selamet Riyadi, "Banking Asset and liability management", Fakultas Ekonomi Un10ersitas Indonesia, Jakarta, 2004, hal 8

${ }_{13}$ Pasal 1 Nomor 20 UU No.21 Tahun 2008, www.google.com

14 Muhammad Ridwan, "Manajemen Baitul maal wat tamwil", UII Press, Yogyakarta, 2005, cet kedua hal 150

15 Ibid, hal 155
} 


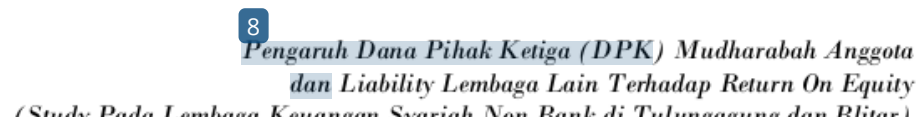

dan Liability Lembaga Lain Terhadap Return On Equity

investasi harta dengan cara sistem mudharabah Islami dapat dibagi menjadi tiga bagian utama yaitu: ${ }^{16}$ keistimewaan moril, keistimewaan sosial dan keistimewaan ekonomi.

keistimewaan moril, keistimewaan sosial dan keistimewaan ekonomi. Keistimewaan moril; sesungguhnya dalam investasi harta dengan cara sistem mudharabah islami dan dalam pandangan hukumhukum dan kaidah-kaidah syariat Islam yang telah ditunjukkan sebelum ini mewujudkan rasa puas secara moril bagi kedua pihak mudharabah yang terpusat pada keta'atan kepada Allah SWT dalam investasi harta dan pendaya-gunaan kemampuan dan pengalaman sesuai dengan yang diridhoi-Nya dan menghindari penimbunan harta dan tidak mengekploitasi (penggunaan yang habis-habisn) terhadap tenaga manusia. Dan dari segi lain memberikan kepada investor (pemilik harta) suatu perasaan bahwa dirinya memiliki peran dalam mewujudkan perkembangan sosial, ekonomi dan pembukaan lahan sum ber rejeki bagi pelaku bisnis (pekerja), dan niscaya juga dia merasakan bobot dirinya dan peran sertanya/partisipasinya dalam masyarakat.

Keistimewaan sosial; investasi harta dengan cara mudharabah menimbulkan penguatan hubungan-hubungan antara investor/pemilik harta dan pelaku bisnis (pekerja), di mana kerja keras menjadi meningkat di dalamnya demi mewujudkan tujuan-tujuan yang telah disepakati atasnya sesuai kontrak mudharabah, dan dari sinilah atas setiap pihak dari beberapa pihak mudharabah harus berusaha keras untuk konsisten terhadap kewajiban-kewajibannya, dan agar selalu menjaga dalam prioritas utama pada keta'atan kepada Allah SWT dan tidak menghianati partner/rekannya, maka pemilik harta mengerahkan/menyerahkan hartanya kepada pelaku bisnis (pekerja) dan dia mengetahui bahwa pelaku bisnis/pekerja adalah jujur dapat dipercaya atas hartanya dan mampu dalam pekerjaannya, dan begitu pula pelaku bisnis/pekerja dengan perannya dalam menjaga harta maka dia konsisten dalam legalitas pekerjaan dan mengerahkan kerja kerasnya semaksimal mungkin untuk mewujudkan profit/keuntungan yang halal bermanfaat bagi semua. Maka dari sinilah rasa kasih sayang dan persaudaraan akan menyelimuti antara beberapa pihak mudharabah, dan bertambah menjadi semakin kuat dan kokoh.

Keistimewaan Ekonomi; termasuk dari keistimewaan ekonomi bagi investasi harta dengan cara sistem mudharabah adalah pemberdayaan yang benar terhadap harta umat islam dan

${ }^{16}$ Musthofa Afifi, Istisymaarul Maali Fil Islami, Wahbah publisher 
pengembangannya dalam proyek-proyek ekonomi berbeda-beda yang dapat mewujudkan kepada pihak-pihak mudharabah kadar optimal (kadar rata-rata) keuntungannya (profit) yang sebanding dengan pertumbuhan yang berlanjut bagi perputaran harta modal, sebagai mana dapat menjaga modal dari pelapukan yang disebabkan oleh penimbunan harta. Dan dari segi lain investasi harta dengan jalan mudharabah dapat mewujudkan bagi masyarakat suatu ketersediaan dana tunai (cash flow) hingga dapat menyediakan bagi pemilik harta bidang yang sesuai untuk investasi sebagai pengganti dari penimbunan harta, yang pada gilirannya dapat mengaktifkan sumber daya manusia (tenaga kerja) dalam masyarakat, maka berputarlah roda produksi dan dengan itu terbentuklah kemapanan ekonomi setelah pendaya-gunaan tenagatenaga pengangguran dalam masyarakat dan berubah menjadi tangantangan yang produktif.

Ada beberapa perbedaan mendasar antara konsep investasi harta dengan cara mudharabah islami dan konsep investasi harta dengan cara sistem riba yang berlangsung atas dasar kredit, dan termasuk dari yang terpentingnya adalah: ${ }^{17}$

Pertama, investasi harta dengan cara mudharabah islami berdiri/berlangsung di atas konsep interaktif antara modal dengan pekerjaan/bisnis untuk mewujudkan perkembangan sosial dan ekonomi, di mana setiap pihak dari kedua belah pihak mengerahkan kerja kerasnya untuk mengembangkan harta dan menambah profit (keuntungan), maka semakin bertambah kerja kerasnya bertambahlah hasilnya, sementara sistem riba berdiri/berlangsung di atas dasar kredit dan jaminan laba yang tetap baginya (bagi sistem ini), dan dengan ini tidak ada pembatas bagi pemilik proyek-proyek dalam bidang pekerjaan.

Kedua, mudharabah berdiri di atas pekerjaan dan harta modal, dan pekerjaan adalah dasar yang pertama karena dialah yang menarik harta pada asalnya, di mana terbentuknya harta itu adalah dari kelebihan yang dihasilkan dari pekerjaan/bisnis, maka dari itu wajarlah bagi setiap modal dan pekerjaan memiliki hak jatah (hak bagian/jatah) dari keuntungan (profit), sedangkan dalam sistem riba kita dapatkan bahwa laba riba (faidah) menghancurkan sistem ini dan mengeksploitasi perkerjaan bagi kepentingan harta modal, karena penghutang (pihak pengambil hutang/kreditor) menjamin kepada pemilik modal hartanya (harta yang menjadi hutang) dan laba yang tetap tanpa pemberi/pemilik harta modal berkongsi dalam kerugian, baik itu penghutang dapat

${ }^{17}$ Ibid. 
mewujudkan/mencapai keuntungan atau kerugian, dan dalam kondisi kedua (kerugian), maka sesungguhnya penghutang menanggung kerugiannya dalam proyek ditambah dengan tanggungan harga laba riba (faidah) bagi pemberi hutang/pemberi riba (murabby) atau pemilik harta modal, sedangkan dalam kondisi mudharabah sesungguhnya pada dasarnya dalam kerugian tidak ditanggung oleh pelaku bisnis/pekerja, bahkan harta modal apabila habis terpakai tidak mencapai keuntungan proyek maka pelaku bisnis/pekerja merugi atas pekerjaan/bisnisnya saja.

Ketiga, investasi harta dengan sistem mudharabah menimbulkan ketiadaan berkumpulnya harta pada tangan lapisan/golongan tertentu, di mana setiap muslim mendapatkan kesempatan dalam investasi harta baik sedikit atau pun banyak, dan pelaku bisnis/pekerja mendapatkan kesempatan untuk mendaya-gunakan kemampuan dan kapabilitasnya, dan dengan begitu setiap individu dalam masyarakat mendapatkan bagiannya dari keuntungan (profit) atau kerugian apabila timbul, dan selanjutnya meleburlah perbedaan-perbedaan, dan arah perjalanan harta tidak didahulukan kepada tangan lapisan/golongan tertentu yaitu lapisan/golongan pelaku riba (pemilik harta modal) yang tidak bekerja dalam masyarakat yang hal itu menimbulkan kemalasan dan tidak produktif dan penarikan harta tanpa timbal balik, sebagai mana penimbunan harta menimbulkan kepada terhalangnya fungsi harta modal dalam masyarakat.

Keempat, investasi harta dengan sistem mudharabah berdiri di atas dasar keseimbangan antara kepentingan individu dan kepentingan orang banyak, dan dalam keadaan pertentangannya, maka kepentingan orang banyak diprioritaskan, sementara dalam sistem riba investasi berdiri di atas dasar monopoli dan eksploitasi dan prioritas kepentingan individu atas kepentingan umum.

Kelima, dalam naungan investasi harta dengan sistem mudharabah islami tidak memberatkan manusia dengan beban-beban keuangan atas komoditas sebagai mana yang biasanya berlaku, bahkan termasuk dari yang pasti adalah bahwa produsen terpaksa menambahkan harga/nominal laba riba (faidah) atas harga komoditas yang pada akhirnya menyebabkan orang-orang menanggung beban laba riba (faidah) sebagai mana masyarakat menanggung beban laba riba (faidah) bagi kredit-kredit pemerintah yang dihutangnya dari badanbadan pemberi kredit dalam bentuk tambahan pajak-pajak yang berbeda-beda, hingga kita lihat bahwa penyebab inflasi keuangan adalah kekurangan sistem keuangan yang termasuk dalam kerangkanya adalah 
laba riba (faidah) di mana laba ini menimbulkan kenaikan harga-harga yang menambah semakin besarnya inflasi.

\section{Kondisi Liability Lembaga Lain Pada Objek Penelitian}

Dana Pihak Ketiga (DPK) cenderung mengalami penurunan baik pada nominal maupun persentase pertumbuhan, yang membuat lembaga keuangan syariah non Bank mengakses dana (liability) dari lembaga lain. Semakin stabil jumlah Dana Pihak Ketiga yang berhasil dihimpun, maka akan meminimalisir kebutuhan liability pada lembaga lain. Kondisi liability lembaga lain yang dibutuhkan oleh BMT di Tulungagung mengalami fluktuasi. Bulan Januari 2017 sebesar Rp. 2.650.682.370,- atau meningkat sebesar 36,7\% dibandingkan bulan sebelumnya. (Laporan Keuangan BMT). Peningkatan permintaan dana dari lembaga lain yang tinggi juga akibat permintaan pembiayaan yang tinggi pula. Akibat dari kebutuhan operasional, baik funding maupun financing, kebutuhan sumber dana dari liability lembaga lain mengalami penurunan yang terbesar yaitu pada bulan April 2017, jumlah liability lembaga lain yang dihimpun sebesar Rp. 1.709.845.840,- atau menurun sebesar 39,62\% dibandingkan bulan sebelumnya.

Sementara pengelolaan Liability lembaga lain BMT di Blitar juga memiliki karakteristik tersendiri. Kebutuhan sumber dana lain tertinggi pada bulan Pebruari 2017 sebesar Rp.131.505.400,- atau sebesar $76,04 \%$ dibandingkan bulan sebelumnya. Kebutuhan sumber dana dari lembaga lain rata-rata mencapai Rp.147,543,733,- atau rata-rata pertumbuhan liability lembaga lain mencapai $23,2 \%$. Jika dibandingkan pada kedua lembaga tersebut, Lembaga Keuangan Syariah di Blitar lebih banyak mengelola dana dari lembaga lain dibandingkan dengan di Tulungagung. Kondisi di atas merupakan jawaban atas dinamika pengelolaan dana pada Lembaga Keuangan Syariah non Bank yang memaksa untuk adaptasi terhadap lingkungan persaingan baik syariah maupun konvensional

Keterbatasan Dana Pihak Ketiga (DPK) dari anggota menjadi bagian pencarian solusi bagi lembaga keuangan syariah non bank untuk berkreasi agar tetap mendapatkan keuntungan yang maksimal. Kondisi akses hutang pada lembaga lain menjadi pilihan dan cenderung stabil. Jika dibandingkan pada kedua lembaga tersebut, Lembaga Keuangan Syariah di Blitar lebih banyak mengelola dana dari lembaga lain dibandingkan dengan di Tulungagung. 


\section{Pengaruh Dana Pihak Ketiga (DPK) Mudharabah Anggota dan Liability Lembaga Lain Terhadap Return On Equity} (Study Pada Lembaga Keuangan Syariah Non Bank di Tulungagung dan Blitar)

Hal ini sesuai dengan penelitian mahasiswa ${ }^{18}$ yang meneliti tentang faktor yang mempengaruhi rasio utang pada perusahaan otomotif di 7ursa Efek menghasilkan bahwa Ukuran perusahaan berpengaruh negatif dan signifikan terhadap DER sedangkan variabel profitabilitas, struktur aset dan likuiditas berpengaruh positif dan signifikan terhadap DER. Hanya variabel peluang pertumbuhan dan kepemilikan institusional yang berpengaruh negatif tetapi tidak signifikan terhadap DER. Hasil penelitian juga menunjukkan bahwa faktor yang paling dominan mempengaruhi DER, secara berurutan, adalah profitabilitas, struktur aset, likuiditas dan ukuran perusahaan. Kondisi kesulitan likuiditas tersebut menjadi kesamaan dalam kebutuhan sumber dana dari lembaga lain pada lembaga keuangan syariah 1on bank.

Manajemen aktiva-pasiva atau Asset-liability management (ALMA) merupakan fokus utama dalam manajemen bank umum. Assetliability management menurut Raflus, pada dasarnya adalah proses perencanaan dan pengawasan operasi perbankan yang dilakukan secara terkoordinasi dan konsekuen dengan selalu memperhatikan perkembangan faktor-faktor yang mempengaruhi operasi bank, baik yang berasal dari luar ataupun faktor struktural dari dalam bank. ${ }^{19}$

Pengelolaan Asset-liability management juga memfokuskan pada koordinasi portofolio aset / liabilitas bank guna memaksimalkan profit bagi bank dan hasil yang dibagikan kepada para pemegang saham dalam jangka panjang dengan memperhatikan kebutuhan likuiditas dan prinsip kehati-hatian. ${ }^{20}$ Pada lembaga keuangan syariah pengelolaan asset dan liabilitas bermanfaat bagi sustainabilility lembaga tersebut. Banyak keterbatasan-keterbatasan yang dimiliki oleh lembaga keuangan syariah, diantaranya hanya diperkenankan untuk melayani terkait anggota, tanpa untuk masyarakat pada umumnya.

Bank syariah dalam melaksanakan fungsi intermediasi memerlukan sumber dana yang mencukupi. Sumber dana bank didefinisikan sebagai usaha bank dalam menghimpun dana dari masyarakat. Menurutnya, perolehan dana ini tergantung dari bank itu

\footnotetext{
18 Faktor yang mempengaruhi debt to equity ratio pada perusahaan otomotif di Bursa Efek Indonesia, diakses melalui http://repository.usu.ac.id/bitstream/handle/123456789/57776/Abstract.pdfjjsessioni $\mathrm{d}=14$ 99DE7C63181A61EB09D6ADE9B3D0E1? sequence $=6$ pada 03 Nopember 2017

${ }^{19}$ Slamet Dahlan, "Manajemen Lembaga Keuangan", cet. ke-4, Lembaga Penerbit FE-UI, Jakarta, 2004, hlm. 142.

${ }^{20}$ Zainul Arifin, "Dasar-dasar Manajemen" Alvabet, Jakarta, 2002, hlm. 121.
}

lqtishadia Vol.5 No.1 Juni 2018 
sendiri, apakah dari simpanan masyarakat atau dari lembaga lainnya. ${ }^{21}$ Ketergantungan terhadap simpanan masyarakat inil 8 merupakan ciri khusus dari Bank Syariah. Hal ini disebabkan hanya Bank Syariah yang diperbolehkan menghimpun dana dari masyarakat langsung.

Sumber dana di Bank Syariah merupakan wujud pengelolaan liability management. Liability management pengelolaan utang bank terhadap pihak ketiga muncul pada saat dana mulai langka dan mahal sebagai dampak semakin banyaknya jumlah bank yang beroperasi, sementara dana terbatas.22 Selain itu dapat diukur dengan menggunakan Debt to Equity ratio. Rasio tersebut merupakan rasio hutang terhadap modal. Rasio ini mengukur seberapa jauh perusahaan dibiayai oleh hutang, dimana semakin tinggi nilai rasio ini menggambarkan gejala yang kurang baik bagi perusahaan ${ }^{23}$.

Rasio hutang/Debt to Equity Ratio (DER) menunjukkan adanya perbandingan total hutang dengan total modal lembaga yang digunakan sebagai operasional usaha. Hutang yang besar menunjukkan bahwa struktur modal lebih banyak memanfaatkan hutang dibanding dengan ekuitas. Semakin besar DER menggambarkan solvabilitas perusahaan semakin rendah sehingga kemampuan perusahaan untuk membayar hutang-hutangnya juga rendah. Bagi investor, semakin besar rasio hutang akan semakin tidak menguntung kan karena akan semakin besar risiko yang ditanggung, kemampuan membayar, dan kemampuan untuk memberikan keuntungan besar. Kondisi tersebut membawa pada risiko yang tinggi bagi lembaga. Tingginya risiko yang harus dikelola menyebabkan investasi pada suatu lembaga akan kurang menarik terutama bagi investor.

Persaingan dengan sesama lembaga keuangan merupakan permasalahan tersendiri sehingga menyebabkan kelangkaan sumber dana masyarakat, sehingga bank syariah mencari alternatif ke dalam sumber lainnya. Keberadaan masyarakat yang menyimpan dananya di Bank Syariah juga berkaitan erat dengan kemampuan dan kemauan masyarakat. Artinya kemauan masyarakat tersebut bisa disebabkan karena banyaknya pilihan atau alternatif lembaga perbankan syariah yang siap menerima titipan/simpanan dana dari masyarakat.

${ }^{21}$ Kasmir "Manajemen Perbankan", Raja Grafindo Persada, Jakarta, 2002, hlm. 53

${ }^{22}$ Frianto Pandia, "Manajemen dana dan Kesehatan Bank", Rineka Cipta, Jakarta, 2012. hlm.181

${ }^{23}$ Agus Sartono, "Manajemen Keuangan-Teori dan Aplikasi" Edisi Keempat, BPFE, Yogyakarta, 2001, hlm. 66. 


\section{蒋 \\ Taruh Dana Pihak Ketiga (DPK) Mudharabah Anggote dan Liability Lembaga Lain Terhadap Return On Equity}

(Study Pada Lembaga Keuangan Syariah Non Bank di Tulungagung dan Blitar)

Operasional lembaga keuangan selain didanai dari simpanan masyarakat, dari bank lain yaitu modal sendiri. Modal sendiri bisa didapat akumulasi para pefiegang saham yang sepakat untuk mendirikan lembaga keuangan. Perolehan dana disesuaikan pula dengan tujuan dari penggunaan dana tersebut. Berkaitan dengan hal tersebut, pemilihan sumber dana akan menentukan besar kecilnya biaya yang ditanggung. Dalam perbankan syariah, biaya yang tertanggung terkait erat dengan bagi hasil yang diperoleh Lembaga Perbankan syariah dari pengelolaan aset. Hasil dari pengelolaan asset akan didistribusikan kepada nasabah penabung, deposito dan bahkan lembaga lain yang ikut serta dalam penyediaan dana. Besar kecilnya tanggungan yang harus dibayar adalah sebesar 15 bah bagi hasil yang disepakati antara sahibul maal dengan mudhorib. Oleh karena itu pemilihan sumber dana harus dilakukan secara tepat. Jika tujuan perolehan dana untuk kegiatan sehari-hari, jelas berbeda sumbernya, dengan jika bank hendak melakukan investasi baru atau untuk melakukan perluasan suatu usaha. Kebutuhan dana untuk kegiatan utama bank diperoleh dalam berbagai simpanan, sedangkan jika kebutuhan dana digunakan untuk investasi baru atau perluasan usaha maka diperoleh dari modal sendiri.

Kebutuhan sumber dana dari lembaga lain juga selain dialami BMT, juga dialami oleh Perbankan. Sumber dana bank terdiri dari modal sendiri (equity), Bantuan kredit likuiditas Bank Indonesia (KLBI), Dana masyarakat (customer deposits) dan dana mahal yang dibeli dari pasar uang. ${ }^{24}$ Liabilitas bank dapat dapat disimpulkan berasal dari: pertama, Dana dari bank itu sendiri (Dana Pihak Pertama), Kedua, Dana dari lembaga lainnya (Dana Pihak Kedua) dan ketiga, Dana dari masyarakat luas (Dana Pihak Ketiga). ${ }^{25}$ Dalam Perbankan Syariah, ketiga sumber dana tersebut satu sama lain memiliki keunikan. Sumber Dana pihak pertama dimaksudkan sebagai dana yang diperoleh dari dalam bank. Sumber dana pihak pertama seringkali berangkat dari orang-orang yang bersepakat mendirikan perbankan syariah. Salah satu jenis dana pihak petama adalah modal setor dari para pemegang saham. Selain itu dana pihak pertama dapat pula berupa cadangan laba, atau laba yang belum didistribusikan kepada para pemegang saham.

Karakteristik dari sumber dana dari pemegang saham adalah berbasis investasi. Artinya para pendiri bank syariah menjadikan modal sebagai pengendali resiko bila terjadi wanprestasi terhadap usaha yang

${ }^{24}$ Frianto pandia, Manajemen dana, hal 182

25 Selamet Riyadi, "Banking Asset and liability management", Fakultas Ekonomi Universitas Indon esia, Jakarta, 2004, hlm. 7

lqtishadia Vol.5 No.1 Juni 2018 
dijalankan. Yang lebih penting dalam hal ini bahwa modal sendiri merupakan dana yang tidak sensitif terhadap keuntungan yang dijalankan. Para pemegang saham memang berharap keuntungan, namun demikian bisnis berpeluang mendapatkan keuntungan dan bahkan kerugian. Dalam perjalanan bank syariah, keuntungan yang dibagikan terhadap para pemegang saham lebih mudah dikenal dengan istilah profit and loss sharing. Yang dibagikan dalam hal ini tidak hanya keuntungan, melainkan juga bila terjadi kerugian, maka ditanggung secara bersama-sama.

Ba 3 lay, Smith dan Watts (1998) dalam Marberyna dan Suaryana $(2009)^{26}$, menyatakan perusahaan yang mempunyai opsi untuk tumbuh lebih besar akan mempunyai utang yang lebih sedikit dikarenakan perusahaan lebih mengutamakan solusi atas masalah-masalah yang berkaitan dengan hutangnya. Dimana perusahaan dengan laba bertumbuh mempunyai kesempatan yang profitable dalam mendanai investasinya secara internal sehingga perusahaan menghindar untuk menarik dana dari luar dan berusaha mencari solusi yang tepat atas masalah-masalah yang terkait dengan hutangnya, selain itu dengan profitabilitas yang meningkat akan meningkatkan laba ditahan sehingga akan mengurangi minat perusahaan untuk melakukan peminjaman dan rasio DER akan menurun.

Laba yang harus dibagikan tidak saja secara keseluruhan, melainkan sesuai cita-cita para pendiri lembaga keuangan, bahwa laba dipergunakan untuk pemupukan modal, sehingga modal akan terus bertambah. Terutama pada awal tahun berjalan. Dalam hal ini manfaat dari sumber dana pihak pertama atau imbalan (bagi hasil) relatif lebih kecil dibandingkan dari sumber lain. Laba yang dibagikan di bank syariah berbeda dengan bank konvensional. Di bank Syariah, pembagian laba dilakukan seiring dengan sifat sosial bank syariah yaitu dikeluarkan zakat dari hasil usaha yang berhasil dikelola. Dalam istilah ekonomi dikenal dengan Earning after Tax and zakah. Zakat yang dikeluarkan bank syariah dalam kerangka untuk menyuburkan ekonomi di masyarakat. Dengan masyarakat terbantu dari zakat yang dikeluarkan oleh perbankan, maka kemampuan masyarakat dalam berusaha meningkat, dan kemampuan untuk menabung juga berbanding lurus.

${ }^{26}$ Ena Marberya, N. P., \& Suaryana, A. (2009). Pengaruh Pemoderasi Pertumbuhan Laba terhadap Hubungan antara Ukuran Perusahaan, Debt to Equity Ratio dengan Profitabilitas pada Perusahaan Perbankan yang Terdaftar di PT. Bursa Efek Jakarta. Jurnal Ilmiah Akuntansi dan Bisnis, 4(1). 
Sumber dana bank syariah yang kedua adalah berasal dari Lembaga Lainnya. Diantaranya berasal dari instrumen money market dan instrumen pasar modal.27 Instrumen pasar uang dalam perbankan syariah berasal dari Pasar Uang Antar bank Syariah (PUAS). Pasar uang antar bank syariah dengan instrumen Sertifikat Investasi Mudharabah (SIMA) berpeluang mendapatkan dana dari bank Konvensional. Dimana Bank Konvensional berkepentingan dalam membeli sertifikat IMA tersebut. Selain itu juga bisa menggunakan akad musyarakah, qardh, wadi'ah dan sharf. ${ }^{28}$ Akad-akad tersebut dalam laporan publikasi di Bank 5yariah yang terwujud dalam liabilitas bank syariah berupa Kewajiban pada Bank Indonesia, Kewajiban pada bank lain, dan surat berharga yang diterbitkan serta kewajiban lainnya. ${ }^{29}$ Jika peluang untuk mendapatkan dari Pasar Uang antar Bank Syariah terbatas, Bank Indonesia memiliki instrumen pemenuhan likuiditas bank syariah melalui Fasilitas Pembiayaan jangka Pendek Bank Syariah (FPJPS). FPJPS mensyaratkan imbalan nisbah bagi hasil sebesar $90 \%$ ke bank Indonesia. ${ }^{30}$ Nisbah bagi hasil untuk Bank Indonesia dinilai sangat tinggi sekali, hingga bank selalu pemanfaat FPJPS hanya mendapatkan $10 \%$. Sumber dana Baitul Maal Wat Tamwil (BMT) yang berasal dari liability lembaga lain adalah sumber dana yang diperoleh dari pinjaman/investasi dari Perbankan Syariah maupun lembaga keuangan lainnya.

Karakteristik dari sumber dana pihak kedua merupakan sumber dana mahal. Mengingat keuntungan yang diminta adalah kemampuan membayar kepada nasabahnya. Kemampuan memberikan keuntungan ini menjadi pilihan karena lembaga keuangan dihadapkan pada persaingan dengan sesama lembaga keuangan, baik sesama syariah maupun konvensional. Unsur liabilitas pada bank syariah juga memiliki unsur pinjaman baik pinjaman diterima maupun pinjaman subordinasi. ${ }^{31}$ Karakteristik pinjaman (subordinated loan) dalam bank syariah dan bank konvesional berbeda sistem operasionalnya. Pinjaman di Bank Syariah menggunakan akad Qard yaitu pinjaman harta yang dapat diminta kembali dan dikategorikan akad tathawwu' yakni akad saling

\footnotetext{
${ }^{27}$ Selamet Riyadi, Banking assets... hal 8

${ }^{28}$ Fatwa Dewan Syariah Nasional nomor 37/DSN-MUI/X/2002 tentang PUAS

${ }^{29}$ Statistik Perbankan syariah juni 2015

${ }^{30}$ Surat Edaran Bank Indonesia no 15/44/DPbS tertanggal 22 Oktober 2013 Fasilitas

Pendanaan jangka pendek syariah bagi Bank umum Syariah

${ }^{31}$ Statistik Perbankan Syariah Juni 2015
} 
membantu dan bukan akad transaksi. ${ }^{32}$ Munculnya pinjaman dalam liabilitas dengan akad qardh yang mendasari operasionalnya, maka pinjaman bukan termasuk dana mahal.

\section{Kondisi Return on Equity pada Objek Penelitian}

Keuntungan menjadi satu tujuan bagi seseorang yang sedang melakukan usaha. Tak terkecuali usaha bersama yang bergabung dalam satu Lembaga Keuangan Syariah non Bank. Keuntungan bagi pemegang ekuitas tergantung seberapa besar Sisa Hasil Usaha diperoleh.

Sisa Hasil Usaha (SHU) pada BMT di Tulungagung cenderung bernilai sepadan, berkisar 3 juta 4 jutaan. SHU tertinggi pada tahun 2017 sebesar Rp. 4.806.800,- terjadi pada bulan Maret. Jika dilihat dari ratarata riil SHU Lembaga Keuangan Syariah non Bank di Tulungagung adalah sebesar Rp. 4.311.258,- atau rata-rata mengalami pertumbuhan menurun sebesar 4,48 persen. Tentu masing-masin wilayah memiliki kemampuan berbeda dalam keberhasilan usaha.

Begitu pula pada BMT di Blitar, keuntungan yang diperoleh Lembaga Keuangan Syariah non Bank di Blitar cenderung mengalami penurunan, namun terdapat satu bulan yang keuntungan tertinggi Rp. 3.885.110,- atau meningkat sebesar 112 persen dibanding bulan sebelumnya. Artinya secara matematis keuntungan yang diperoleh BMT di Tulungagung.

Jika ditinjau dari modal yang dimiliki lembaga, maka semakin melengkapi kondisi profitabilitas lembaga keuangan Syariah non Bank. Modal Lembaga Keuangan Syariah non Bank di Tulungagung mengalami fluktuasi yang cenderung mengalami penurunan. Data tertinggi pada bulan Januari 2017 sebesar Rp. 570.331.184,- atau meningkat sebesar 7,56\%, dan terendah pada bulan Juni 2017 sebesar Rp. 518.018.024,-Penurunan modal terendah pada pada bulan Pebruari 2017 menurun sebesar 7 persen. Rata-rata modal yang dimiliki selama 6 bulan di tahun 2017 sebesar Rp. 534,722,025,- dan jika dilihat dari rata-rata pertumbuhannya menurun sebesar 0,3 persen.

Kondisi Modal berbeda yang terjadi pada Lembaga Keuangan Syariah non Bank di Blitar. Modal pada Lembaga Keuangan syariah non bank di Blitar memiliki nominal seperlima dibandingkan dengan BMT Mu'amalah di Tulungagung. Modal tertinggi berjumlah Rp. 147.005.247,. Jumlah ini menurun 5,31\% dibandingkan bulan sebelumnya. Data

32 Zainul Arifin, "Dasar-dasar manajemen Bank Syariah", Azkia Publisher, Tangerang, 2009, hlm. 161 


\section{Pengaruh Dana Pihak Ketiga (DPK) Mudharabah Anggota dan Liability Lembaga Lain Terhadap Return On Equity (Study Pada Lembaga Keuangan Syariah Non Bank di Tulungagung dan Blitar)}

Modal terendah pada bulan Juni 2017 yaitu sebesar Rp. 105.534.681,-, artinya seiring berjalannya waktu tidak ada peningkatan modal. Penurunan tingkat modal terbanyak pada bulan Mei 2017 menurun sebesar 11,59\%. Rata modal yang dimiliki selama kurun waktu 6 bulan sebesar 129,900,534,-. Atau rata-rata pertumbuhan modal menurun sebesar 6,11\%.

Modal yang dimiliki BMT memberikan kontribusi terhadap keuntungan bagi pemegang ekuitas. Keuntungan tertinggi bagi pemilik equitas di BMT Mu'amalah Tulungagung terjadi pada bulan Maret dan April 2017, masing-masing sebesar 0,9\%. Profitabilitas bagi ekuitas terendah pada bulan Pebruari dan Juni 2017. Rata-rata keuntungan bagi pemilik ekuitas sebesar 0,8\%. Keuntungan bagi pemegang ekuitas pada BMT di Blitar lebih besar dibandingkan dengan keuntungan yang terjadi di BMT Muamalah Tulungagung. Return on equity tertinggi pada bulan Mei 2017 sebesar 3,34 persen dan terendah pada bulan Pebruari 2017 sebesar 0,6 persen. Rata-rata return on equity dalam 6 bulan mencapai 1,46 persen.

Tujuan utama investasi adalah untuk mendapatkan nilai tambah atas dana yang diinvestasikan. Kondisi keuntungan bagi pemegang ekuitas tergantung seberapa besar Sisa Hasil Usaha Lembaga keuangan syariah diperoleh. Sisa Hasil Usaha di Lembaga keuangan Syariah non Bank di Tulungagung menampilkan data SHU cenderung bernilai sepadan dan cenderung mengalami penurunan, namun masih relatif stabil pada Return on equity BMT di Blitar. Kondisi ini sesuai dengan penelitian Dwiarti ${ }^{33}$ yang meneliti tentang faktor yang mempengaruhi profitabilitas pada perusahaan manufaktur yang terdaftar di BEI bahwa debt to equity ratio tidak signifikan mempengaruhi return on equity. Namun dalam penelitian pada kedua lembaga tersebut, berhubungan secara negatif.

Lembaga keuangan mikro syariah dalam operasionalnya memiliki keterkaitan 6 ngan modal yang dimiliki. Modal Baitul maal wat tamwil sebagaimana modal koperasi yang berasal dari setoran pokok dan sertifikat modal koperasi. ${ }^{34}$ Setoran pokok merupakan setoran yang (6) bayar anggota saat mendaftar sebagai anggota. Selain hal di atas, modal koperasi juga berasal dari Hibah, modal penyertaan, modal pinjaman (anggota, koperasi lainnya, bank dan lembaga keuangan

33 Rina Dwiarti, Evaluasi faktor yang mempengaruhi profitabilitas pada perusahaan manufaktur yang terdaftar di BEI, Jurnal Sosio - Humaniora, Vol 5 No 2, September 2014, ISSN no 2087 - 1899

34 Undang-undang nomor 17 tahun 2012 tentang Perkoperasian. 
lainnya, penerbitan obligasi dan surat berharga lainnya, Pemerintah/pemerintah daerah serta sumber lain yang tidak bertentangan dengan undang-undang. 35 Pada lembaga syariah, pinjaman menggunakan akad qardh. Namun demikian dalam lembaga keuangan mikro syariah apakah yang digunakan adalah pinjaman? Pertanyaan tersebut menjadi sulit dirasionalkan tatkala lembaga keuangan lain atau bank lain bertujuan untuk mendapat keuntungan. Dari lembaga lain bisa jadi menggunakan istilah penyertaan modal dengan akad mudharabah atau musyarakah.

Sumber dana di Baitul Maal Wat Tamwil (BMT) identik dengan sumber dana di Bank Syariah yaitu merupakan sumber dana pihak pertama yang terdiri dari Simpanan pokok khusus (modal penyertaan), simpanan pokok dan simpanan wajib. ${ }^{36}$ Simpanan khusus tersebut merupakan modal penyertaan yang dimiliki oleh individu maupun lembaga dengan jumlah setiap penyimpan tidak harus sama, dan jumlah dana tidak mempengaruhi suara dalam rapat. Modal penyertaan ini biasanya dikumpulkan dari hasil pendekatan kepada sejumlah orang baik secara personal maupun lembaga. Kepada orang yeng menyertakan dana khusus ini mendapatkan sisa hasil usaha di akhir tahun berjalan.

Simpanan pokok memiliki pengertian suatu dana yang harus dibayar saat menjadi anggota Baitul Maal Wat Tamwil (BMT). ${ }^{37}$ Besaran simpanan pokok ditentukan oleh lembaga sehingga nominal yang harus dibayar oleh setiap anggota adalah sama. Teknis pembayaran simpanan pokok bisa dilakukan secara bertahap, sehingga memberi kemudahan bagi calon anggota bergabung. Simpanan pokok ini sebagai bukti keanggotaan seseorang dalam sebuah BMT, sehingga hanya bisa diambil saat keluar dari anggota. Pada saat seseorang menarik simpanan pokok maka dengan sendirinya keanggotaan dalam sebuah Baitul Maal Wat Tamwil (BMT) sudah lepas. Hasil yang dikumpulkan dari simpanan pokok tersebut oleh Baitul Maal Wat Tamwil (BMT)diperuntukkan sebagai akumulasi dari modal yang digunakan untuk membiayai lembaga baik untuk kegiatan operasional maupun untuk kegiatan investasi.

Simpanan wajib merupakan simpanan ketiga yang menjadi modal BMT. Simpanan wajib meruapkan modal yang terus mengalir

${ }^{35}$ Ibid. Undang-undang koperasi nomor 17 tahun 2012

36 Muhammad Ridwan, "Manajemen Baitul Maal wa Tamwil (BMT)", UII Press, Yogyakarta, 2005, cet ke2, hlm. 153

37 Ibid, hal 154 


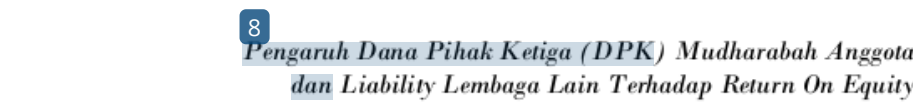

dan Liability Lembaga Lain Terhadap Return On Equity

(Study Pada Lembaga Keuangan Syariah Non Bank di Tulungagung dan Blitar)

setiap waktu. $^{38}$ Besar kecilnya simpanan wajib ditentukan oleh kemampuan dan kemauan anggota, dan sifatnya rutin sesuai kesepakatan. Oleh karenanya masing-masing anggota berbeda nilai nominal simpanan pokok yang ditaruh di lembaga. Nilai keuntungan dari simpanan wajib dan simpanan pokok diperhitungkan dalam pembagian Sisa Hasil Usaha (SHU).

Simpanan anggota yang berhasil dihimpun oleh Lembaga keuangan mikro syariah seperti BMT membutuhkan dukungan sumber dana yang diperoleh dari ekuitas atau modal sendiri. Dalam mengelola sumber dana sendiri tentu BMT berharap bisa memberikan keuntungan bagi penyertaan modal yang ada dalam ekuitas. Pantas kiranya untuk meneliti lebih mendalam terkait profitabilitas yang dilihat dari sisi Return on Equity. Pemikiran terhadap keuntungan pada ekuitas berarti menaruh harapan atas kesejahteraan bagi pemilik dana. Kesejahteraan dalam hal ini adalah kesejahteraan dalam kehidupan duniawi yang berdampak pada kesejahteraan ukhrawi para pemilik dana.

Masyarakat yang melakukan investasi dana pada umumnya memiliki tujuan; pertama, mendapatkan kehidupan yang layak di masa depan. Hal ini biasanya bisa dilakukan dengan meminimalisir pengeluaran pada masa tertentu, dan berharap di masa yang akan datang dapat digunakan untuk kebutuhan. Kedua, beradaptasi dengan kekuatan inflasi. Bisnis yang dijalankan dapat memberikan pendapatan dan menghindarkan diri dari penurunan nilai uang akibat inflasi yang terjadi. Ketiga, proses hemat untuk mengelola pajak. Hal ini berguna untuk mendorong investasi di masyarakat. ${ }^{39}$

Keuntungan bagi pemilik ekuitas yang diukur dengan (Return on Equity). Hal ini mengukur peluang lembaga Keuangan dalam memperoleh laba atau Sisa Hasil usaha yang menjadi hak bagi pemegang saham Baitul Maal wat Tamwil. Alasan mendasar seseorang akan menginvestasikan atau ikut mendirikan lembaga keuangan diantaranya karena faktor return. Artinya bahwa jika seseorang mau bergabung mendirikan lembaga keuangan syariah non bank adalah karena menaruh harapan untuk mendapatkan keuntungan dari dana yang diinvestasikan atau yang disertakan.

Keuntungan yang diharapkan oleh investor merupakan kompensasi atas biaya kesempatan (opportunity cost) dan risiko penurunan daya beli barang karena inflasi. ${ }^{40}$ Keuntungan yang

${ }^{38}$ Ibid, Muhammad Ridwan, hal 154

${ }^{39}$ Eduardus Tandelilin, "Portovolio dan investasi", Kanisius, Yogyakarta, 2010 hlm. 8-9

${ }^{40}$ Ibid. H. 9-10 
diharapkan (expected return) oleh investor tentunya memiliki kesamaan ataupun bahkan berbeda dengan keuntungan yang direalisasikan (actual return). Sering kali pemilik dana menaruh harapan besar kepada lembaga untuk mendapatkan keuntungan yang besar. Kondisi ini memacu lembaga untuk terus mengelola dana yang dimiliki agar memberikan keuntungan yang maksimal. Tidak sedikit lembaga yang memilih pembiayaan yang bersifat pasti. Memilih portofolio asset yang memberikan untuk besar, baik dalam bentuk surat berharga maupun pembiayaan atau bahkan menaruh dananya pada tempat lain.

Risiko memberikan hubungan yang linear terhadap return aktual, artinya semakin besar resiko asset, maka semakin besar return harapan diperoleh. ${ }^{41}$ Risiko pengelolaan dana dari lembaga lain yang memberikan risiko tinggi berharap memberikan nilai positif terhadap keuntungan bagi lembaga.

Profitabilitas merupakan indikator yang paling tepat untuk mengukur kinerja suatu bank ${ }^{42}$. Profitabilitas pada industri perbankan diukur menggunakan Return On Equity (ROE) dan Return On Asset (ROA). Return On Asset (ROA) memfokuskan kemampuan perusahaan untuk memperoleh earning dalam opersasinya, sedangkan Return On Equity (ROE) hanya mengukur return yang diperoleh dari investasi pemilik perusahaan dalam bisnis tersebut ${ }^{43}$.

Perusahaan dalam masa pertumbuhan, akan memperkuat hubungan antara hutang (DER) dengan profitabilitas. Profitabilitas akan meningkat seiring dengan DER yang rendah. Sebagaimana pendapat Porter (1980 : 161) dalam Hamid (2001), mengemukakan bahwa perusahaan yang berada pada fase pertumbuhan mempunyai margin dan profit yang tinggi. Sedangkan Anthony dan Ramesh (1992) dalam Hamid (2001) ${ }^{44}$ menemukan pertumbuhan laba lebih besar pada perusahaan yang sedang tumbuh. Dalam hal ini munculnya hutang pada dasarnya secara teori akan dihindari untuk mengembangkan perusahaan. Dalam konteks Lembaga keuangan mikro syariah, hutang

41 Ibid. H.11

${ }^{42}$ Sofyan Syafri Harahap, "Akuntansi Aktiva Tetap", Edisi Pertama, Penerbit PT. Raja Grafindo Persada, Jakarta, 2002

43 Bhlan Siamat, "Manajemen Lembaga Keuangan" PT. Gramedia Pustaka, 2002.

44 Hamid, ABD. Habbe. "Studi terhadap Pengukuran Kinerja Akuntansi Perusahaan Prospektor dan Defender dan Hubungannya dengan Harga Saham: Analisis dengan Pendekatan Life Cycle Theory". Jurnal Riset Akuntansi Indonesia, Vol. 4, No 1, Januari 2001. hal. 111-132. STIE Yo. (Januari) 2001: 40-56. 
mendapat porsi tersendiri untuk bisa memperkuat porsi usaha, meskipun hanya memiliki sedikit modal.

\section{Pengaruh DPK Mudharabah Terhadap Return On Equity}

DPK mudharabah diperoleh Baitul Maal Wat Tamwil dari simpanan anggota, baik dalam simpanan mudharabah maupun deposito mudharabah. DPK mudharabah sebagai sumber dana operasional BMT untuk bisa disalurkan kepada anggotanya dalam bentuk pembiayaan. Hasil penelitian ini menunjukkan bahwa DPK mudharabah memberikan pengaruh tidak signifikan terhadap return on Equity lembaga. Sebagaimana penelitian Meilita ${ }^{45}$ yang meneliti pengaruh sumber dana pihak ketiga terhadap profitabilitas BSM Cabang Cirebon dan hasilnya adalah dengan metode korelasi spearman rank menghasilkan sebesar 0,1489 atau sebesar $14,9 \%$. Artinya sebesar $85,1 \%$ yang berkorelasi terhadap profitabilitas adalah variabel selain Dana Pihak ketiga. Hal tersebut bisa disebabkan karena jaringan Bank Syariah Mandiri secara nasional dan orientasi lembaga yang berbeda. Begitu juga yang terjadi pada BMT di Tulungagung dan Blitar, DPK mudharabah yang masih terbatas jumlahnya, berdampak pada keterbatasan lembaga dalam mengelola dana dalam bentuk pembiayaan. Terbatasnya pembiayaan pada BMT berdampak pada keuntungan yang diperoleh.

Penelitian Sudiyatno dan Suroso ${ }^{46}$ menghasilkan bahwa DPK berpengaruh positif dan signifikan terhadap ROA pada saham perbankan yang sudah go public di BEI. Artinya peran dana pihak ketiga pada perbankan yang bersifat terbuka mampu mengembangkan lembaga dengan baik. Menurut H. Nyadin ${ }^{47}$, orientasi BMT adalah untuk keummatan, sehingga pemegang ekuitas menyadari bahwa untuk urusan keummatan, maka dibutuhkan pengorbanan. Dalam kondisi seperti ini yang penting tidak mengalami kerugian. Tujuan utama BMT adalah membantu anggota yang membutuhkan fasilitas pembiayaan untuk mengembangkan ushaa. Oleh karenanya, jika ta'awun ini menjadi prinsip utama, maka pemegang ekuitas menyadari akan peran dan

45 Nita Meilita, Pengaruh Sumber dana pihak ketiga terhadap Profitabilitas pada BSM Cabang (Cirebon, Skripsi, IAIN Syekh Nurjati Cirebon; 2011)

${ }^{46}$ Sudiyatno, B., \& Suroso, J. (2010). Analisis Pengaruh Dana Pihak Ketiga, BOPO, CAR Dan LDR terhadap Kinerja Keuangan Pada Sektor Perbankan yang Go Public Di Bursa Efek Indonesia (BEI) (Periode 2005-2008). Dinamika Keuangan dan Perbankan, 2(2). Jurnal.

${ }^{47}$ Hasil Wawancara dengan manajer PINBUK Tulungagung, pada Jum'at, 13 Oktober 2017 pukul 09.30 WIB 
kontribusinya dalam perekonomian, sehingga keuntungan menjadi nomor kedua setelah proses membantu dijalankan, dengan catatan tidak sampai uang yang dikelola menjadi berkurang.

Penelitian ini sejalan dengan penelitian Yuliani (2007) ${ }^{48}$, memperlihatkan bahwa MSDN/DPK berpengaruh positif dan tidak signifikan terhadap Return On Asset (ROA). Hal ini juga berbeda dengan penelitian Sulistianingrum ${ }^{49}$ dimana bahwa DPK memberikan pengaruh negatif terhadap Profitabilitas. sebesar 2, 985 sedangkan secara simultan (bersama-sama) variabel FDR, DPK, SBIS dan NPF berpengaruh positif terhadap ROA.

\section{Pengaruh Liability Lembaga Lain Terhadap Return On Equity}

Kondisi masing-masing lembaga keuangan dalam memperoleh sumber dana berbeda-beda. BMT dengan basis legalitas di bawah naungan koperasi, maka sumber dana berasal dari anggota. Undangundang terbaru membolehkan sumber dana diperoleh dari lembaga lain.50 Pada BMT Podojoyo Blitar, sumber dana diperoleh dari simpanan anggota berupa simpanan wadi'ah, mudharabah, dan deposito mudharabah. Tak terkecuali, mengingat permintaan pembiayaan yang tinggi maka BMT Podojoyo Blitar melakukan kerjasama dengan Puskopsyah BMT Mu'amalah dan yang lainnya. Anggota pada BMT Podojoyo dibedakan menjadi dua, anggota yang menyetorkan dana minimal Rp. 2.500.000,- sebagai penyertaan modal, dan anggota yang secara sukarela menyimpan dana maupun melakukan transaksi pembiayaan dan hutang piutang. ${ }^{51}$

Hasil penelitian menunjukkan bahwa kerjasama yang dilakukan kepada lembaga keuangan lainnya memberikan pengaruh negatif, namun tidak signifikan secara statistik. Hal tersebut disebabkan bahwa lembaga tersebut mengedepankan keuntungan anggota penyimpan

48 Yuliani, 2007. Hubungan Efisiensi Operasional dengan Kinerja Profitabilitas pada Sektor Perbankan yang Go Public di Bursa Efek Jakarta, Jurnal Manajemen dan Bisnis Sriwijaya, Vol. 5, No. 10, Desember, 2007.

${ }^{49}$ Dwi Rahayu Sulistianingrum, Analisis pengaruh FDR, DPK, SBIS, dan NPF terhadap Re 6 . $n$ on Equity (Jakarta; UIN Syarif Hidayatullah; 2013)

50 Dalam (6) dang-Undang no 17 tahun 2012, dijelaskan bahwa sumber dana koperasi diperoleh dari setoran pokok dan se 6 ifikat modal koperasi. Point kedua ditambahkan modal bisa diperoleh dari hibah, koperasi lainnya/anggotanya, bank dan lembaga keuangan lainnya, penerbitan obligasi dan sejenisnya, serta pemerintah dan pemerintah daerah.

51 Wawancara dengan Suprihno, Manager pelaksana Puskopsyah BMT Podojoyo Blitar, 13 Oktober 2017, pukul 15.00 WIB 
dana, serta keuntungan bagi lembaga lain. Menurut Suprihno, bahwa anggota penyimpan dana diberikan keuntungan pasti 1 persen/ bulan. ${ }^{52}$ Kondisi tersebut yang berdampak pada SHU yang di dapat lembaga menjadi sedikit. Padahal dalam bagi hasil, keuntungan diberikan sesuai tingkat keuntungan yang di dapat melalui nisbah bagi hasil. Hal tersebut dilakukan dengan tujuan agar tetap jalannya perekonomian masyarakat, dalam pembiayaan yang sifatnya syariah. Hal ini yang diinterpretasikan niat menolong ummat diterapkan. Walaupun tidak dipungkiri, pada saat SHU rendah, para anggota aktif merasa kurang puas.

Kondisi di atas sejalan dengan penelitian Marlina dan Danica53 dalam penelitiannya bahwa rasio hutang terhadap permodalan tidak signifikan mempengaruhi pembayaran dividen. Namun dalam penelitian Sidabutar, yang bertujuan untuk mengetahui Analisis Pengaruh Kepemilikan Institusi, Net Profit Margin, Debt To Equity Ratio, dan RasioRasio Bank terhadap Return On Equity menghasilkan bahwa rasio hutang (DER) signifikan berpengaruh positif terhadap ROE perusahaan. ${ }^{54}$ Selain itu dalam penelitian Akbar, yang melakukan penelitian tentang Analisis Pengaruh Loan to Deposit Ratio (LDR) dan Debt to Equity Ratio (DER) Terhadap Kinerja Keuangan Return On Equity (ROE) menghasilkan bahwa, DER mempunyai pengaruh yang signifikan terhadap ROE. ${ }^{55}$ Rasio hutang yang berpengaruh positif terhadap return on equity terjadi bila hutang yang dilakukan mampu dikelola dalam asset yang produktif, dengan volume pembiayaan yang tinggi pula. Selain itu dilakukannya prinsip efisiensi dalam pengelolaan operasional. Artinya setiap karyawan memberikan kontribusi terhadap besarnya lembaga.

\section{Pengaruh DPK Mudharabah dan Liability Lembaga Lain Terhadap Return On Equity}

Tujuan orang investasi dan mendirikan BMT secara bersamasama tentunya bermacam-macam. Adakalanya bergabungnya dalam mendirikan BMT karena keyakinannya terhadap pengembangan

52 Wawancara dengan Suprihno, Manager pelaksana Puskopsyah BMT Podojoyo Blitar, 13 Oktober 2017, pukul 15.00 WIB

${ }^{53}$ Marlina, L., \& Danica, C. (2009). Analisis Pengaruh Cash Position, Debt To Equity Ratio, Dan Return On Assets Terhadap Divident Payout Ratio.

${ }^{54}$ Sidabutar, Analisis Pengaruh kepemilikan institusi, NPM, DER, dan rasio-rasio Bank terhadap Return on Equity, http://eprints.undip.ac.id 2007

55 Shofar Akbar „Ali, "Analisis Pengaruh Loan to Deposit Ratio (LDR) dan Debt to Equity Ratio (DER) terhadap Kinerja Keuangan Return On Equity (ROE) Perusahaan Perbankan di Indonesia Tahun 2009-2013." Dalam http://eprints.ums.ac.id/36604/1/NASKAH\%20 PUBLIKASI.pdf. Diakses 11 Januari 2016. 
ekonomi Syariah. Namun juga tidak sedikit yang bertujuan untuk mendapatkan profitabilitas. Cita-cita dan semangat tersebut menjadi cakrawala bagi BMT untuk mengelola keuangan syariah dengan sistem operasional yang sesuai. Penelitian ini menghasilkan bahwa secara simultan, DPK mudharabah dan liability pada lembaga lain memberikan memberikan pengaruh yang tidak signifikan terhadap return on equity. Kondisi demikian berbeda dengan Penelitian Yuliani (2007) ${ }^{56}$, memperlihatkan bahwa secara bersama-sama / secara simultan, variabel FDR, DPK, SBIS dan NPF berpengaruh positif terhadap ROA. Begitu juga dalam Penelitian Marlina dan Danica ${ }^{57}$ bahwa peran bersama antara Cash position, DER, ROA terhadap dividen payout ratio sebesar 0,27 satuan. Perbedaan ini disebabkan bahwa jika murni dilihat dari sumber dana dan karakteristik sumberdana, memberikan pengaruh yang tidak signifikan, oleh karenanya perlu dimasukkan juga tentang peluang pengelolaan asset produktif.

Penelitian Damayanti yang menguji pengaruh ukuran (size), capital adequacy ratio (CAR), Pertumbuhan deposit, loan to deposit rasio (LDR), terhadap Profitabilitas. Diantara hal yang mempengaruhi secara signifikan terhadap ROE adalah ukuran (size) dan Capital adequacy ratio (CAR)..$^{58}$ artinya bahwa pemilik ekuitas akan mendapatkan keuntungan jika memiliki kecukupan modal untuk menyangga setiap resiko dalam pengelolaan asset. Selain itu besar-kecilnya BMT juga menjadi warna untuk mendapatkan keuntungan yang positif.

Penelitian Wati yang bertujuan untuk mengetahui Analisis Pengaruh BOPO, NIM, GWM, LDR, PPAP dan NPL terhadap ROE menghasilkan bahwa NIM, dan LDR secara parsial berpengaruh positif dan Signifikan terhadap ROE. ${ }^{59}$ Kondisi keuntungan bersih yang tinggi

56 Yuliani, 2007. Hubungan Efisiensi Operasional dengan Kinerja Profitabilitas pada Sektor Perbankan yang Go Public di Bursa Efek Jakarta, Jurnal Manajemen dan Bisnis Sriwijaya, Vol. 5, No. 10, Desember, 2007.

57 Marlina, L., \& Danica, C. (2009). Analisis Pengaruh Cash Position, Debt To Equity Ratio, Dan Return On Assets Terhadap Divident Payout Ratio.

58 Pupik Damayanti, "Analisis Pengaruh Ukuran (Size), Capital Adequacy Ratio (CAR), Pertumbuhan Deposit, Loan To Deposit Rasio (LDR), terhadap Profitabilitas Perbankan Go Public Di Indonesia tahun 2005- 2009 (studi empiris perusahaan perbankan yang Terdaftar di BEI)". Jurnal Ilmu Manajemen dan Akuntansi Terapan (JIMAT) Vol.3, No.2, $\begin{array}{llll}\text { November } & \text { Tahun } & 2012 . & \text { Dalam }\end{array}$ http://jurnal.stietotalwin.ac.id/index.php/jurnalilmumanajemendanakunta/article/dow nload /79/76. diakses 25 Februari 2016

${ }_{59}$ Erna Wati, "Analisis Pengaruh BOPO, NIM, GWM, LDR, PPAP dan NPL terhadap ROE Pada Bank Go Public dan Non Go Public Di Indonesia Periode Tahun 2007-2009." Dalam http://eprints.undip.ac.id/37556/3/JURNAL.pdf. diakses 24 Maret 2015 
akan memberikan keuntungan yang positif pula bagi pemilik ekuitas, dalam hal ini adalah pendiri BMT. Selain itu banyak tidaknya pembiayaan juga menjadikan keuntungan yang diperoleh akan tinggi, oleh karenanya diperlukan penguatan terhadap pengelolaan asset produktif.

Penelitian Wisnala dan Purbawangsa yang menganalisis pengaruh Struktur Modal Terhadap Profitabilitas Sebelum Dan Setelah Krisis Global Pada Perusahaan Perbankan Di Bursa Efek Indonesia menunjukkan bahwa menunjukkan DAR, DER, LDER, dan LDAR berpengaruh secara silmutan terhadap profitabilitas perusahaan perbankan di Bursa Efek Indonesia sebelum dan setelah krisisi global tahun $2008 .{ }^{60} \mathrm{Hal}$ ini juga senada dengan penelitian Akbar, bahwa Secara simultan LDR dan DER mempunyai pengaruh yang signifikan terhadap ROE. ${ }^{61}$

\section{PENUTUP}

Pengelolaan BMT membutuhkan kinerja yang tinggi agar dapat menghasilkan tujuan lembaga. Hasil penelitian Pengaruh DPK mudharabah dan liability pada lembaga lain terhadap Return On Equity pada lembaga keuangan syariah non Bank di Tulungagung dan Blitar adalah:

1. Kondisi Dana Pihak Ketiga (DPK) mudharabah anggota mengalami fluktuasi baik di Tulungagung maupun, di Blitar cenderung mengalami penurunan.

2. Kondisi liability lembaga lain, lebih banyak dibutuhkan di Blitar, dibandingkan di Tulungagung.

3. Kondisi return on equity lebih besar di dapat di Blitar daripada di Tulungagung.

4. DPK mudharabah berpengaruh positif namun tidak signifikan secara statistik terhadap return on equity BMT di Tulungagung dan Blitar

5. Liability pada lembaga lain memberikan pengaruh negatif dan tidak signifikan secara statistik terhadap return on equity BMT di Tulungagung dan Blitar

${ }^{60}$ Vudha Wisnala, dan Ida Bagus Anom Purbawangsa, "Analisis pengaruh Struktur Modal Terhadap Profitabilitas Sebelum Dan Setelah Krisis Global Pada Perusahaan Perbankan Di Bursa Efek Indonesia." Jurnal Wisnala Vol. 3, No. 2, Tahun 2014.

${ }_{61}$ Shofar Akbar „Ali, "Analisis Pengaruh Loan to Deposit Ratio (LDR) dan Debt to Equity Ratio (DER) terhadap Kinerja Keuangan Return On Equity (ROE) Perusahaan Perbankan di Indonesia Tahun 2009-2013." Dalam http://eprints.ums.ac.id/36604/1/NASKAH\%20 PUBLIKASI.pdf. Diakses 11 Januari 2016. 
6. Secara simultan variabel DPK mudharabah dan liability pada lembaga lain memberikan pengaruh dan tidak signifikan secara statistik terhadap return on equity BMT di Tulungagung dan Blitar

\section{(1)aftar Rujukan}

Adiwarman A.Karim, Bank Islam (Analisis Fiqih dan Keuangan), Jakarta: PT.Raja Grafindo Persada, 2004

Ahmad Tanzeh dan Suyitno, Dasar-Dasar Penelitian, Surabaya: Lembaga Kajian Agama dan Filsafat (eLKAF), 2006)

Ascarya, Akad dan Produk Bank Syariah, Jakarta: PT RajaGrafindo Persada, 2008.

Dahlan Siamat. Manajemen Lembaga Keuangan: PT. Gramedia Pustaka 2002.

Dwi Rahayu Sulistianingrum, Analisis pengaruh FDR, DPK, SBIS, dan NPF terhadap Return on Equity, Jakarta; UIN Syarif Hidayatullah; 2013

Dwi Rahayu Sulistianingrum, Analisis pengaruh FDR, DPK, SBIS, dan NPF terhadap Return on Equity, Jakarta; UIN Syarif Hidayatullah; 2013

Ena Marberya, N. P., \& Suaryana, A.. Pengaruh Pemoderasi Pertumbuhan Laba terhadap Hubungan antara Ukuran Perusahaan, Debt to Equity Ratio dengan Profitabilitas pada Perusahaan Perbankan yang Terdaftar di PT. Bursa Efek Jakarta. Jurnal Ilmiah Akuntansi dan Bisnis, 4(1). 2009

Ena Marberya, N. P., \& Suaryana, A. Pengaruh Pemoderasi Pertumbuhan Laba terhadap Hubungan antara Ukuran Perusahaan, Debt to Equity Ratio dengan Profitabilitas pada Perusahaan Perbankan yang Terdaftar di PT. Bursa Efek Jakarta. Jurnal Ilmiah Akuntansi dan Bisnis, 4(1). 2009

Erna Wati, "Analisis Pengaruh BOPO, NIM, GWM, LDR, PPAP dan NPL terhadap ROE Pada Bank Go Public dan Non Go Public Di Indonesia Periode Tahun 2007-2009." Dalam http://eprints.undip.ac.id/37556/3/JURNAL.pdf. diakses 24 Maret 2015

Faizi, Faktor-Faktor Yang Mempengaruhi Simpanan Mudharabah Pada Bank Umum Syariah (Periode 2005-2007). Skripsi thesis, UIN Sunan Kalijaga Yogyakarta, 2010

Fatwa Dewan Syariah Nasional nomor 37/DSN-MUI/X/2002 tentang PUAS 
Pengaruh Dana Pihak Ketiga (DPK) Mudharabah Anggoto dan Liability Lembaga Lain Terhadap Return On Equity (Study Pada Lembaga Keuangan Syariah Non Bank di Tulungagung dan Blitar)

Frianto Pandia, Manajemen dana dan Kesehatan Bank, Jakarta, Rineka Cipta, 2012

Hamid, ABD. Habbe. 2001. "Studi terhadap Pengukuran Kinerja Akuntansi Perusahaan Prospektor dan Defender dan Hubungannya dengan Harga Saham: Analisis dengan Pendekatan Life Cycle Theory". Jurnal Riset Akuntansi Indonesia, Vol. 4, No 1, Januari 2001. hal. 111-132. STIE Yo. (Januari) : 40-56.

Harahap, Sofyan Syafri, Akuntansi Aktiva Tetap , Edisi Pertama, Penerbit PT. Raja Grafindo Persada, Jakarta. 2002

Hasil Wawancara dengan manajer PINBUK Tulungagung, pada Jum'at, 13

1 Oktober 2017 pukul 09.30 WIB

Herman Darmawi, Pasar Finansial dan Lembaga-lembaga Finansial, Jakarta: PT Bumi Aksara, 2006

Tasmir. Manajemen Perbankan. Jakarta: Raja Grafindo Persada, 2002

M. Sulhan dan Ely Siswanto, Manajemen Bank: Konvensional dan Syariah, Malang: UIN-Malang Press, 2008

M. Syafi'i Antonio, Islamic Banking, Bank Syariah dari Teori ke Praktik, Jakarta: Gema Insani Press, 2001

Marlina, L., \& Danica, C. Analisis Pengaruh Cash Position, Debt To Equity Ratio, Dan Return On Assets Terhadap Divident Payout Ratio. 2009

Muhamad, Manajemen Dana Bank Syariah, Yogyakarta: Ekonisia, 2004

Muhammad Ridwan, Manajemen Baitul Maal wa Tamwil (BMT), Yogyakarta, UII Press, 2005, cet ke2

Muhammad, Manajemen Bank Syariah, (Yogyakarta: UPP AMP YKPN, 2002), hlm.48.

Musthofa Afifi, Istisymaarul Maali Fil Islami, Wahbah publisher

Nita Meilita, Pengaruh Sumber dana pihak ketiga terhadap Profitabilitas pada BSM Cabang Cirebon, Skripsi, IAIN Syekh Nurjati Cirebon; 2011

Pupik Damayanti, "Analisis Pengaruh Ukuran (Size), Capital Adequacy Ratio (CAR), Pertumbuhan Deposit, Loan To Deposit Rasio (LDR), terhadap Profitabilitas Perbankan Go Public Di Indonesia tahun 2005- 2009 (studi empiris perusahaan perbankan yang Terdaftar di BEI)". Jurnal Ilmu Manajemen dan Akuntansi Terapan (JIMAT) Vol.3, No.2, November Tahun 2012. Dalam http://jurnal.stietotalwin.ac.id/index.php/jurnalilmumanajemen danakunta/article/download /79/76. diakses 25 Februari 2016

RAT masing-masing BMT di bawah Naungan PINBUK Tulungagung. 
Rina Dwiarti, Evaluasi faktor yang mempengaruhi profitabilitas pada perusahaan manufaktur yang terdaftar di BEI, Jurnal Sosio Humaniora, Vol 5 No 2, September 2014, ISSN no 2087 - 1899

Sartono, Agus. Manajemen Keuangan "Teori dan Aplikasi". Edisi Keempat. Yogyakarta: BPFE, 2001

Selamet Riyadi, Banking Asset and liability management, Jakarta, Fakultas Ekonomi Universitas Indonesia, 2004

Shofar Akbar „Ali, "Analisis Pengaruh Loan to Deposit Ratio (LDR) dan Debt to Equity Ratio (DER) terhadap Kinerja Keuangan Return On Equity (ROE) Perusahaan Perbankan di Indonesia Tahun 20092013." Dalam http://eprints.ums.ac.id/36604/1/NASKAH\%20 PUBLIKASI.pdf. Diakses 11 Januari 2016.

Sidabutar, Analisis Pengaruh kepemilikan institusi, NPM, DER, dan rasiorasio Bank terhadap Return on Equity, http://eprints.undip.ac.id 2007

Slamet Dahlan, Manajemen Lembaga Keuangan, cet. ke-4 Jakarta: Lembaga Penerbit FE-UI, 2004

Soetanto Hadinoto, Bank Strategi On Funding and Liability Management, Jakarta: PT Gramedia, 2008

Statistik Perbankan syariah juni 2015

Sudiyatno, B., \& Suroso, J. Analisis Pengaruh Dana Pihak Ketiga, BOPO, CAR Dan LDR terhadap Kinerja Keuangan Pada Sektor Perbankan yang Go Public Di Bursa Efek Indonesia (BEI)(Periode 20052008). Dinamika Keuangan dan Perbankan, 2(2). Jurnal. (2010).

Sugiono, Statistik Untuk Penelitian, Bandung: Alfabeta, 2006

Surat Edaran Bank Indonesia no 15/44/DPbS tertanggal 22 Oktober 2013 Fasilitas Pendanaan jangka pendek syariah bagi Bank umum Syariah

Thabrani, Abdul Mukti. "MUDHARABAH PERSPEKTIF AVERROES (Studi Analisis Kitab Bidayat al-Mujtahid Wa Nihayat al-Muqtashid)." IQTISHADIA: Jurnal Ekonomi \& Perbankan Syariah 1, no. 1 (28 November 2014):

1-14. https://doi.org/10.19105/iqtishadia.v1i1.362.

(1) Thdang-Undang no 17 tahun 2012

Undang-undang No.21 tahun 2008, www.google.com.Diakses tanggal 20 6 Agustus 2014.

Undang-undang nomor 17 tahun 2012 tentang Perkoperasian.

Vudha Wisnala, dan Ida Bagus Anom Purbawangsa, "Analisis pengaruh Struktur Modal Terhadap Profitabilitas Sebelum Dan Setelah 
Pengaruh Dana Pihak Ketiga (DPK) Mudharabah Anggota dan Liability Lembaga Lain Terhadap Return On Equity (Study Pada Lembaga Keuangan Syariah Non Bank di Tulungagung dan Blitar)

Krisis Global Pada Perusahaan Perbankan Di Bursa Efek Indonesia." Jurnal Wisnala Vol. 3, No. 2, Tahun 2014.

Wawancara dengan Suprihno, Manager pelaksana Puskopsyah BMT Podojoyo Blitar, 13 Oktober 2017, pukul 15.00 WIB

Wawancara dengan Suprihno, Manager pelaksana Puskopsyah BMT 1 Podojoyo Blitar, 13 Oktober 2017, pukul 15.00 WIB

Wiroso, Penghimpunan Dana dan Distribusi Hasil Usaha Bank Syariah, Jakarta: PT Grasindo, 2005

Yuliani, 2007. Hubungan Efisiensi Operasional dengan Kinerja Profitabilitas pada Sektor Perbankan yang Go Public di Bursa Efek Jakarta, Jurnal Manajemen dan Bisnis Sriwijaya, Vol. 5, No. 10, Desember, 2007.

Zainul Arifin, Dasar-dasar Manajemen, Jakarta: Alvabet, 2002

Zainul Arifin, Dasar-dasar manajemen Bank Syariah, Tangerang, Azkia Publisher, 2009 
Pengaruh Dana Pihak Ketiga (DPK) Mudharabah Anggota dan Liability Lembaga Lain Terhadap Return On Equity (Study Pada Lembaga Keuangan Syariah Non Bank di Tulungagung dan Blitar)

ORIGINALITY REPORT

$12 \%$

SIMILARITY INDEX

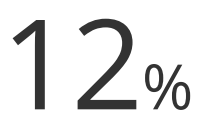

INTERNET SOURCES
$4 \%$

PUBLICATIONS
$4 \%$

STUDENT PAPERS

PRIMARY SOURCES

1 www.scribd.com

2 ejournal.stainpamekasan.ac.id Internet Source

3 directory.umm.ac.id Internet Source

5 www.repository.uinjkt.ac.id Internet Source

6 fr.scribd.com Internet Source

7 id.123dok.com Internet Source 
9 eprints.uny.ac.id Internet Source

Exclude quotes On

Exclude matches

$<1 \%$

Exclude bibliography On 